\title{
共析鋼極細線の疲労強度に及ぼす腐食環境の影響*
}

\author{
笠場孝 一*1, 片桐一宗*1, 佐藤 正*1 \\ 正路良孝*1, 藤野 契*2 \\ 田代均*3, 児玉順一*3
}

\section{Effect of Corrosive Environments on the Fatigue Strength of Eutectoid Steel Wires}

Koichi KASABA*4, Kazumune KATAGIRI, Tadashi SATO, Yoshitaka SHOJI, Hisashi FUJINO,

Hitoshi TASHIRO and Jyunichi KODAMA

${ }^{* 4}$ Department of Mechanical Engineering. Iwate University:

4-3-5 Ueda, Morioka shi, Iwate, 020-8551 Japan

\begin{abstract}
The fatigue strength of eutectoid steel wires was investigated by rotating bending tests under various corrosive environments. The high cycle fatigue strength was remarkably lower in air at relative humidity of $70 \%$ as compared with those at 30 to $50 \%$ and even in distilled water. Although the strength in $\mathrm{NaCl}$ aqueous solution was lower than that in distilled water, no appreciable difference was found among the $\mathrm{NaCl}$ solution with concentration of $1 \%$ and $0.1 \%$ and also in the solution analogous to that in the tire absorbed solution. Although the effect of dissolved oxygen concentration in the tire absorbed solution on the fatigue strength was small, that of the hydrogen ion concentration was large in the region of $\mathrm{PH} 7$ to 10 , slightly smaller at $\mathrm{pH} 2$ and no effect at $\mathrm{pH} 12$. Fractographic observations revealed that pitting corrosion is dominant in $\mathrm{pH} 7$ to 10 , while the general corrosion is dominant in $\mathrm{pH} 2$.
\end{abstract}

Key Words: Corrosion Fatigue, Fractography, Crack Propagation, Eutectoid Steel Wire, Dissolved Oxygen, Hydrogen Ion Concentration, Relative Humidity, $\mathrm{NaCl}$ Solution

\section{1.}

共析鋼極細線は，ワイヤーロープ用素線や自動車用 ラジアルタイヤおよび高圧ホース等のゴム補強用スチ 一ルコードとして機械・土木などの各工業分野で広く 使用されている. 共析鋼極細線は安価で高強度, 大量 生産が可能であるという特長を有しているため，その 需要は年々増加の傾向にあり，またその使用環境も多 種多様となって過酷さも増大している.

このように工業用材料として重要な位置を占めてい る共析鋼極細線は，今後ますます需要が高まるととも に疲労はもとより種々の腐食性環境・摩耗などに対し てより優れた特性を兼ね備えていることが必要不可欠 となってくる. しかしながら, 強加工され, 微視組織 が高度に配向することで U.T.Sで 3000MPa 級を実現し たこのような極細線の腐食疲労挙動や耐環境特性は,

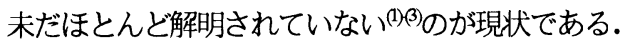

本研究では，共析鋼極細線の各種環境因子が疲労強 度およひ破壊機構に及ぼす影響を明確にすることを目

$*$ 原稿受付 2003 年 4 月 9 日.

*1 正員, 岩手大学工学部(画020-8551 盛岡市上田 4-3-5).

$* 2$ 岩手大学大学院工学研究科.

*3 新日本製鐵(株) 釜石製鐵所 (昰 020-8567 釜石鈴子町 23-15)

E-mail : kasaba@iwate-u.ac.jp
的とする.

\section{2. 実众林料およひ方法}

\section{1 供武材}

供試材は JS SWRS82A に準じた共析鋼極細線(49.9で， その化学組成を表 1 に，機械的特性を表 2 に示す。試 験片は丸棒圧延材に熱処理と伸線加工を数回絽返して 伸線された線径 $03 \mathrm{~mm}$ ，伸線加工ひずみ $(\varepsilon) 3.54$ の極細 線である. 本研究での伸線加工ひずみは, 伸線加工最 終熱処理後の線径 $\left(d_{0}\right)$ から仕上がり線径 $(d)$ までの加工 率を意味しており，

$$
\varepsilon=2 \ln \left(\frac{d_{0}}{d}\right)
$$

\section{で定義される.}

\section{2 実方法}

実験に使用した疲労試験機は，ハンタ一式回転曲げ 疲労試験機(図 1:東鋼機製 $\mathrm{TF}-2$ )である. 腐食環境の 疲労試験は, 各線材の曲率部を溶液に浸漬した状態下 で行った。応力比は-1, 綝返し速度は大気中のものは $3000 \mathrm{cpm}$ ，溶液中のものは $1000 \mathrm{cpm}$ ，室温および溶液 


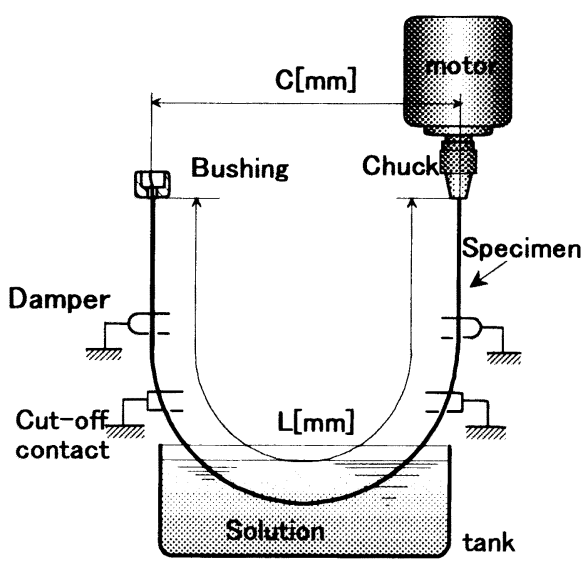

Fig1Schematic ill stration of Hum turtype fatignetes incomosive atmoxphere

温度は $20 \pm 2^{\circ} \mathrm{Cに}$ 制御した. なお本研究の疲労限は応 力綝返し数 $1 \times 10^{7}$ で破断しない繰返し曲げ応力とする. 疲労試験後, 破断線材を走査型電子顕微鏡(SEM)を 用いて観察を行った.

\section{3 実程}

実験環境は以下の通りである.

(1) 相刘湿度(RH)の影響として RH30\%以下(低湿度), $\mathrm{RH} 50 \pm 5 \%$ (中湿度), RH $70 \%$ 以上(高湿度)の大気中 と蒸留水中

(2) $0.1 \%$ およ゙ $1 \% \mathrm{NaC}$ 水溶液

(3) 水素イオン濃度(PH)をPH2,710,12に調整した夕イ 中内水分組成液中

(4) 溶存酸素量 $(0,10 \mathrm{mgl})$ を制御した PH7 のタイヤ内 水分組成液中.

ここでタイヤ内水分組成液とは自動車の夕イヤ内水分 と類似した環境を人工的に作成した腐食溶液である. この溶液の化学組成を表 3 に示す．また，PH 調整液 として $\mathrm{NaOH}$ および $\mathrm{HQ}$ を用い，溶存酸素を調整する ために Arガスによるバブリングを行った.

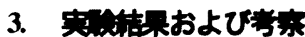

共析鋼極細線は，強い腐食作用の影響のもとでは疲 労強度は低く，疲労限は示さない．この寿命低下の原 因となる環境因子を調べるために，前述した(1)〜出の ように各条件を変化させた.

\section{1 相対湿度の的}

低湿度，中湿度および高湿度大気中，蒸留水中の環 境下で疲労試験を行い, 得られた S-N曲線を図 2 に示 す.
Table1 Chemicalcompositions[wt\%]

\begin{tabular}{|c|c|c|c|c|c|}
\hline & $\mathrm{C}$ & $\mathrm{Si}$ & $\mathrm{Mn}$ & $\mathrm{P}$ & $\mathrm{S}$ \\
\hline SWRS82A & 0.81 & 0.21 & 0.50 & 0.011 & 0.015 \\
\hline
\end{tabular}

Table2 Mechanicalproperties

\begin{tabular}{|c|c|c|c|}
\hline $\begin{array}{c}\text { Diameter } \\
\text { [mm] }\end{array}$ & $\begin{array}{c}\text { Drawing } \\
\text { strain }\end{array}$ & $\begin{array}{c}\text { U.T.S } \\
\text { [MPa] }\end{array}$ & $\begin{array}{c}\text { RA } \\
{[\%]}\end{array}$ \\
\hline 0.3 & 3.54 & 3116 & 45.5 \\
\hline
\end{tabular}

Table 3Chemical compositionsof tire absorbed solution[W\%]

\begin{tabular}{|c|c|c|}
\hline $\mathrm{NaCl}$ & $\mathrm{NaNO}_{3}$ & $\mathrm{NaSO}_{4}$ \\
\hline 0.03 & 0.06 & 0.09 \\
\hline
\end{tabular}

図 2 より高湿度大気中，蒸留水中の環境では，本実 験での応力振幅領域 300 1600MPa に疲労限度は確認 されず，これらの環境が線材の疲労強度に大きな亜影 響を与えているものと考えられる. また, 高湿度大気 中と蒸留水中の S-N曲線を比較すると高湿度大気中が やや低い疲労強度を示すことが確認された. 高湿度大 気中では, 大気中の水分が金属面で凝結して水膜とな り，腐食を起こすものと考えられる.さらにその場合 は蒸留水中の浸漬試験のに比べ酸素の供給量が潤沢な ため, 酸素の還元反応がより活発で、結果として腐食 が促隹すると考えられる。一方, 相刘湿度 70\%の高 サイクル領域の疲労強度の低下はかなり激しい。一般 に材料の腐食速度が急激に増加し始める相刘湿度, つ まり臨界湿度 $\left(\mathrm{RH}_{\mathrm{c}}\right)$ が存在し，鉄鋼材料に関しては $\mathrm{RH}_{c} \doteqdot 60 \%$ と報告されているの. 今回の結果にもその 傾向が見られる.

差はわずかであるが, 低サイクル領域では高サイク ル領域とは逆で高湿度もしくは蒸留水中での疲労強度 の方が高いことがわかる.この逆転現象は鋼の水中疲 労に関して報告されておりの，上田らのは理由として 水による冷却作用を上げている. 低サイクル領域は局 所的であっても応力ーひずみ線図のヒステリシスルー

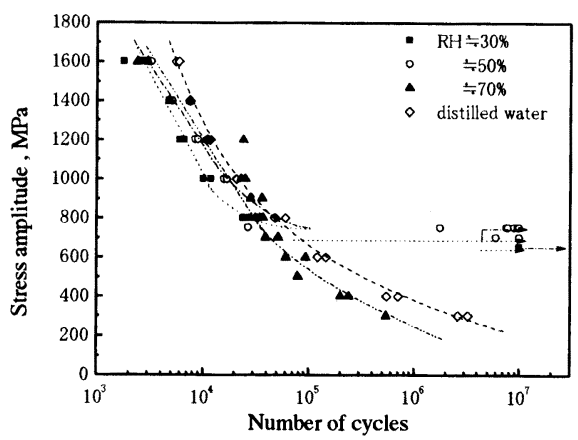

Fig2 Effect of humidity on S-N curve 
プで示される塑性変形を伴うため, 試験片は幾らか発 熱する. 蒸留水や水膜がその冷却作用により試験片の 温度を低下させ，また腐食の化学反応を遅らせている ことが考えられる。

\section{3. $2 \mathrm{NaClの}$}

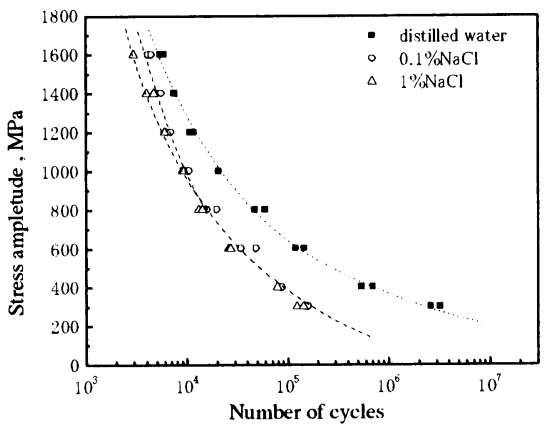

Fig 3 Effect of concentration of $\mathrm{NaCl}$ on $\mathrm{S}-\mathrm{N}$ curve

環境中の中性塩の濃度が共析鋼極細線の疲労強度に 及ぼす影響を調べるため, $0.1 \% \mathrm{NaC}$ および $1 \% \mathrm{NaC}$ 水溶液中, 蒸留水中での疲労試験により得られた S-N 曲線を図 3 に示す. 応力繰返しのごく初期に発生した 腐食ビットがその後の繰返しとともに成長し、十分な 応力集中が得られる寸法になったときにき裂が発生す る(1).ひとたびき裂ができたものは低応力下でも破壊 へと進むため、疲労限は消失する。繰返し応力による すべりによって生成する活性な新生面での $\mathrm{Fe}^{2+}$ の溶解, それに対する電気的中性を保つための $\mathrm{a}^{-}$の泳動と溶 液の加水分解による水素イオン濃度(PH)の低下，こ れらのことが腐食ピットの形成とその後のき裂進展を 促進させていると考えられる。なお一般の炭素鋼につ いて，カソード分極を行った状態で，同様の $\mathrm{NaC}$ 溶 液下の疲労試験を行うと，腐食ピットによるき裂の初 生を抑えることになり，図2の大気中での試験のよう な疲労限が復活するという報告がある(11).

低サイクル領域で $0.1 \% \mathrm{NaC}$ 水溶液中の疲労強度は $1 \% \mathrm{NaCl}$ 水溶液のものと差異が見られ，蒸留水中の強 度に接近する傾向にある. $\mathrm{a}^{-}$が低濃度の場合, 浸漬 時間の短い低サイクル側では，その泳動量は不十分で PH の低下が緩いと考えられる，一方，高サイクル側 では, NaO の濃度の違いによる S-N 曲線の変化はあ まり認められなかった. よって十分な浸漬時間か確保 されれば, 試験片周辺, とりわけ引張り側の曲げ応力 が常に最大となるU字型となった試験片(図 1)の凸部 近傍の， $\mathrm{a}^{-}$の濃縮は飽和するものと思われる.

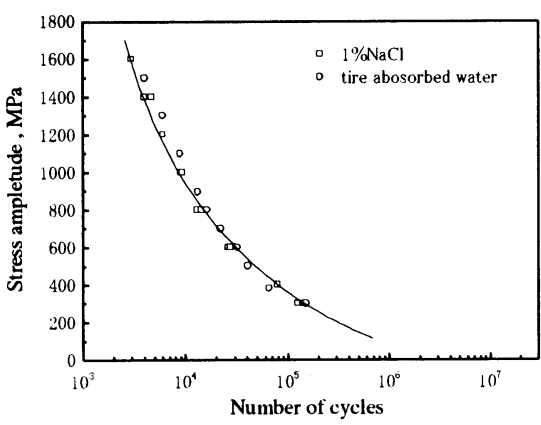

Fig 4 Effects of environment on S-N curve (1\% NaCland tire absorbed water)

一方，共析鋼極細線が補強材としてよく使用される 自動車用夕イヤ中に近い成分の溶液, タイヤ内水分組 成液中での疲労試験によって得られた $\mathrm{S}-\mathrm{N}$ 曲線を図 4 に示す。この $\mathrm{S}-\mathrm{N}$ 曲線は, $1 \% \mathrm{NaC}$ 水溶液中と差 異がない。この溶液中の $\mathrm{NO}_{3}^{-}$や $\mathrm{SO}_{4}^{2-}$ も $\mathrm{a}^{-}$と同様に 腐食を促進させる効果を有すると考えられる.

\section{3 水素イオン渻度の影}

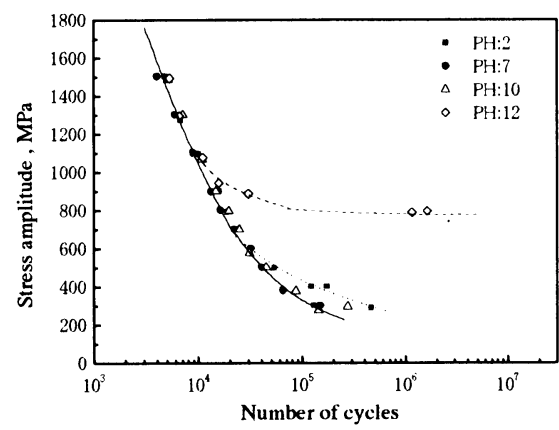

Fig5 Effects of hydrogen-ion concentration on S-N curve

環境中の水素イオン濃度が共析鋼極細線の疲労強度 に及ぼす影響を調べるため，PH 27,10,12 と PH を調整 した上述のタイヤ内水分組成液での疲労試験によって 得られた SN曲線を図5に示す。

環境の影響が少ないと考えられる高応力低寿命域， すなわち低サイクル領域では PH の依存性がほとんど 見られなかった.一方, 高寿命低応力振幅域，つまり 高サイクル領域では $\mathrm{PH}, 10$ で強度の差異は見られな いが, PH12 では S-N 曲線に明確な疲労限か現れた。 PH12 では実験後の試験片表面が低・中湿度大気中と 同様に金属光沢を呈していた。低応力振幅域の自然電 位下，高アルカリ域では鉄は安定な不働態莫を形成す 


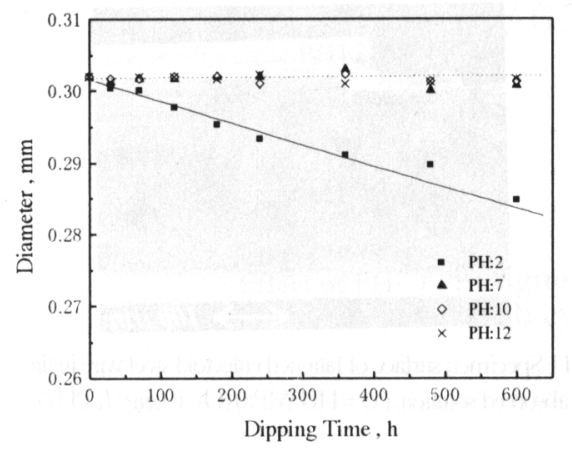

Fig,6 The relationship between dipping time and wire diameter in the corrosive envimment

るため, 腐食損傷のない線材表面となつたものと考え られる.PH2 の酸性域は溶液中に水素イオンが多く存 在するため，中性域より腐食反応は進み，図6のよう に線径が減少する.これは他の PHでは見られないこ とである。腐食はPHD以上の孔食型に対し，PH2は全 面腐食型であると言える。なお PH2 で絽返し応力 300MPa のとき，破断までに線径が 03 から $0.29 \mathrm{~mm}$ 細くなった. そのため PH2 に限っては公称応力と真 応力に違い $(300 \rightarrow 291 \mathrm{MPa})$ が出てくる. 高サイクル領 域で PH2 が PH7,10 より強度が若干高くなっているの は，全面腐食と局所腐食のメカニズムの違いの他に， その効果も含まれていると考えられる.

\section{4 溶存酸素の影算}

タイヤ内水分組成液などの中性の溶液中における炭 素鋼の腐食基本物質は水と酸素である。一般に溶液中 に酸素が溶存していると， $\mathrm{H}^{+}$の還元反応に代わり， $\mathrm{O}_{2}$ の還元反応が起こる. 溶液中の酸素が共析鋼極細線の 疲労強度に及ぼす影響を調べるため, 夕イヤ内水分組 成液を大気中に放置した場合（溶存酸素濃度は約

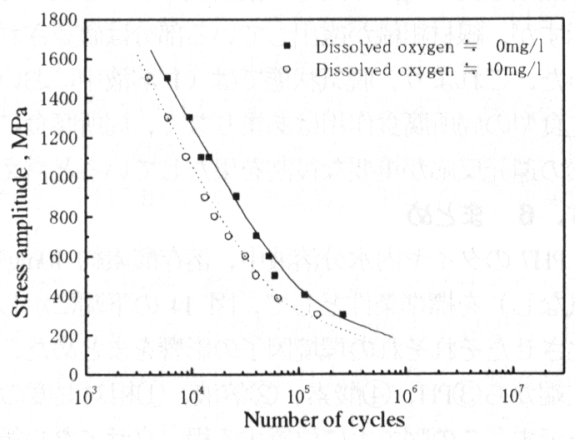

Fig.7Effects of dissolved oxygen ion on S-N curve in the tire absorbed solution
$10 \mathrm{mgl}$ で 3.3 節までの実験はこれに相当）と Arガス によって酸素を脱気した場合(溶存酸素濃度 : 約 $0 \mathrm{mgl}$ ) における疲労試験によって得られた S-N曲線を図 7 に 示す.

図7より二つの曲線に差か確認され, 低サイクル領 域, 高サイクル領域ともに脱気した溶液中で疲労強度 の改善が見られる.これは図 3 の低サイクル則でのみ 違いが垷れる溶液の中性塩の濃度の影響, 図 5 の高サ イクル側でのみ違いが現れる PH の影響とは異質であ る. 疲労の全領域にわたつて $\mathrm{O}_{2}$ の還元反応は活性で, 損傷過程促售の一要因となっていると考えられる.

\section{5 SEM観察}

各環境中での疲労試験後の破面, 線材表面の様相を 図 8〜13 に示す. なお観察には高サイクル領域と低 サイクル領域の代表值としてそれぞれ 300MPa， 1100MPaを作用させた試験片を使用した.

\section{5.1 破面観察}

共析鋼極細線の破断面の形態は大別して, 軸方向に 縦割れを伴う階段状の面(戝 8), またはその縦割れ部 がねじれているもの(戝9), および軸方向に対して垂 直な平面(図.10)の 2 種類とこれらの混合する夕イブが 確認された. 高応力振幅域は, 四8や四9のようにそ の破断形状は複雑であり大きな軸方向への割れととも に，面積の小さい破面を数段の階段状に形成している のが確認された。つまり進展した複数のき裂が軸方向

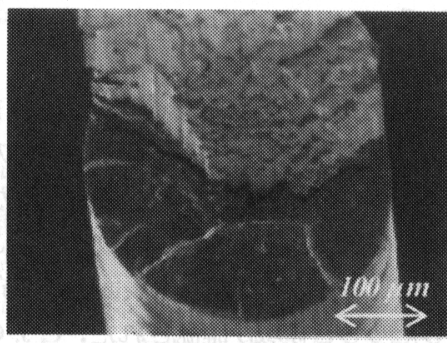

Fig8. Fractograph of fatigued eutectoid steel wire in tire absorbedsolution $(\sigma=1100 \mathrm{MPa})\left(\mathrm{O}_{2}: 10 \mathrm{mg} / \mathrm{l}, \mathrm{PH} 7\right)$

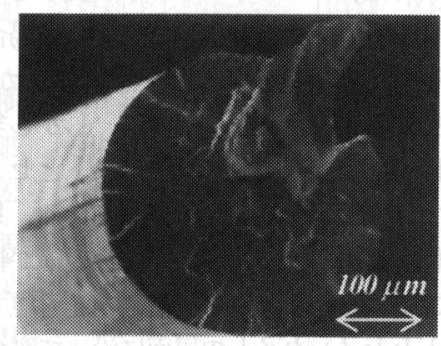

Fig.9 Fractograph of fatigued eutectoid steel wire in tire absorbed solution. $(\sigma=1100 \mathrm{MPa})\left(\mathrm{O}_{2}: 10 \mathrm{mg} / \mathrm{l}, \mathrm{PH} 7\right)$ 


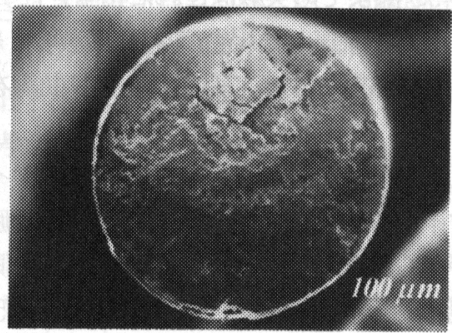

Fig.10Fractograph of fatigued eutectoid steel wire in tire absorbed solution. $(\sigma=300 \mathrm{MPa})\left(\mathrm{O}_{2}: 10 \mathrm{mg} / \mathrm{l}, \mathrm{PH} 7\right)$

の割れによって連結し，最終破断を引き起こしたと考 えられる.一方, 低応力振幅域では図 10 に観察され たように軸方向に対して垂直な平面での破断が多く見 られた。その破面にはき裂発生およびその近傍の比較 的平滑な面と，き裂が進展し破断に至る直前の粗い面 が存在し，2つの領域に区分される. 腐食作用の大き い夕イヤ内水分組成液中 $(\mathrm{NaCl}$ 水溶液中も同様) は, 図 10 の断面下端部に見られるくぼみを起点にしてき 裂が発生，進展している.このくぼみ（後述の図 11, 12）は伸線加工時に生じた残留応力と負荷応力による 応力腐食割れ，または水素ぜい化によるバーライトコ ロニ一境界での割れ，もしくは介在物と腐食の作用で 生じた表面部損傷が原因となって存在すると思われる。 これら形状的不均一部分の応力集中場か破壊の起点と なっている.

\section{5.2 表面観察}

図 11〜13 は表面写真の一例を示す. 四 11 に示すよ うに夕イヤ内水分組成液中の高応力振幅域の表面には， 軸方向に垂直なたくさんのき裂が観察された。一方， 同じ環境中の図 12 の低応力振幅域の表面には，き裂 はあまり確認されないが，材料表面の軸方向に繊維状 に溶解したらしき領域か確認された。 C. J. Cron ${ }^{(2)} ら に$ よるとセメンタイトの腐食は環境の酸化還元性に大き く影響を受け，例えば PH4 付近では存在する陰イオ ンによっては, フェライトのみが腐食する $\mathrm{SO}^{+}$の場合， またセメンタイトのみが溶解する $\mathrm{Cl}^{-}$の場合，そして それが電位によってどちらが溶解するかが異なる $\mathrm{NO}_{3}$ と様々であると指摘している. しかし多くの場合 は腐食は不純物が偏析するフェライトとセメンタイト の界面で優先的に起こると報告している．共析鋼極細 線は伸線加工により層状パーライト組織が軸方向に配 向したコロニーからなっていることを考慮すると，フ エライトとセメンタイトの界面に沿って腐食が進み, 場合によってはセメンタイトまたはつェライトが溶解

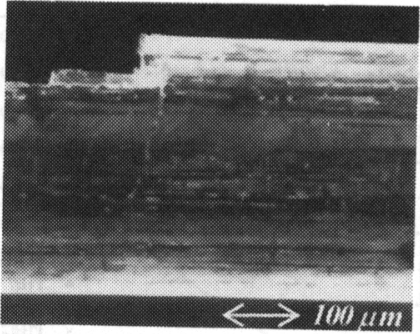

Fig.11Specimen surface of fatigued entectoid steel wire in tire absorbed solution. $(\sigma=1100 \mathrm{MPa})\left(\mathrm{O}_{2}: 10 \mathrm{mg} / \mathrm{l}, \mathrm{PH} 7\right)$

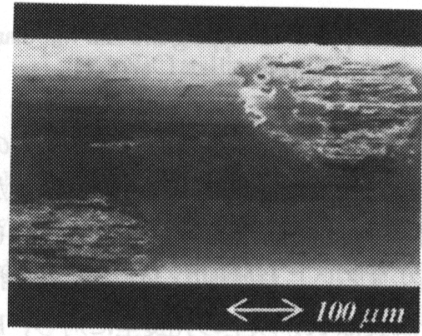

Fig.12 Specimen surface of fatigued eutectoid steel wire in tire absorbed solution... $(\sigma=300 \mathrm{MPa})\left(\mathrm{O}_{2}: 10 \mathrm{mg} / \mathrm{l}, \mathrm{PH} 7\right)$

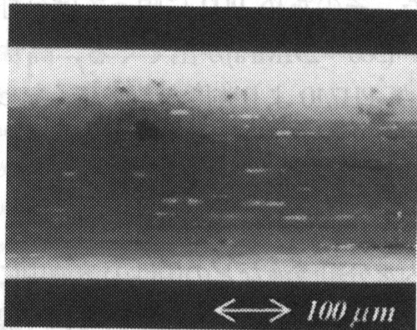

Fig,13 Specimen surface of fatigued eutectoid steel wire in tire absorbed solution. $(\sigma=300 \mathrm{MPa})\left(\mathrm{O}_{2}: 0 \mathrm{mg} / \mathrm{l}, \mathrm{PH} 7\right)$

もしくは脱落しこのような繊維状の腐食痕をつくつた ものと考えられる.このように腐食は孔食型ではある が, 局所的な広がりをみせている。一方, 眓 14 は溶 存酸素量約 Omgl の低応力振幅域における表面写真を 示すが，線材組織が露出している部分は確認されなか った.これより，脱気状態では $\mathrm{a}^{-}$溶液中においても 孔食型の局所腐食作用はあまりなく, 局所腐食には酸 素の還元反応が重要な役割を果たしていると言える.

\section{6 まとめ}

PH7 の夕イヤ内水分溶液中, 溶存酸素約 10mgl（脱 気なし）を標準条件として，図 14 の下端に示し，変 化させたそれぞれの環境因子の影響をまとめた．四の 左端から(3)PH, (4)酸素, (2)溶液, (1)相対湿度の影響 を示す。この戝で上に位置する程, 高サイクル領域で の疲労強度が高いことを示す。 


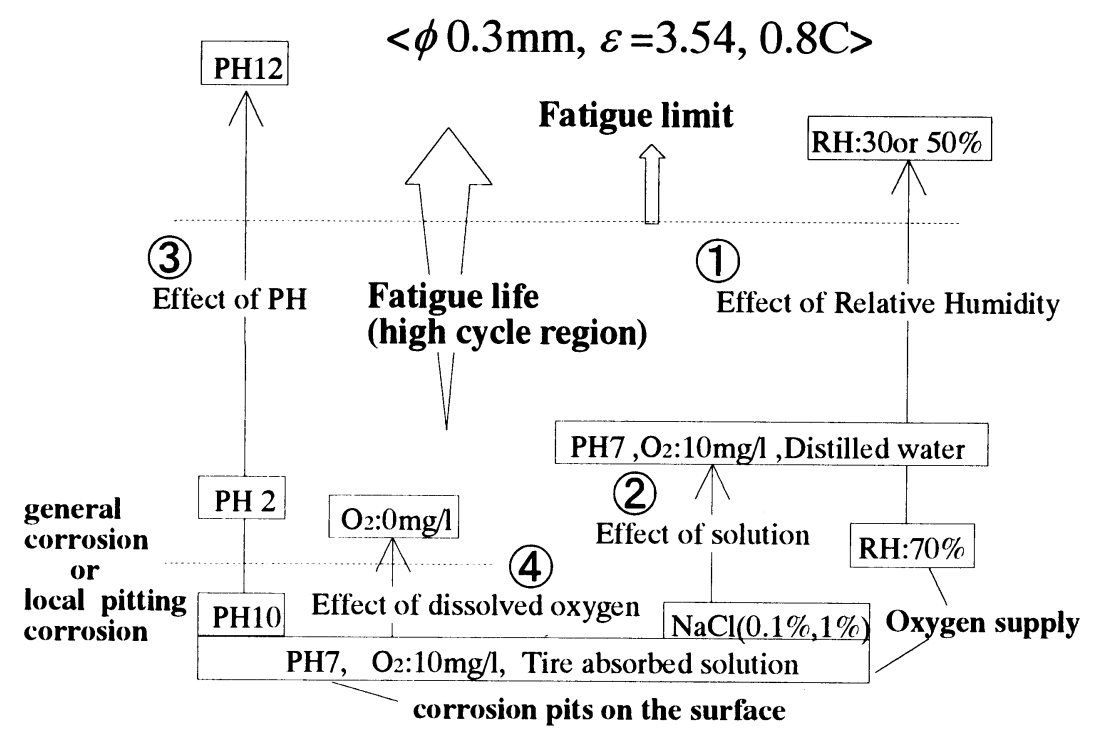

Fig14Comparison of fatigne strength (high cycle fatigne region) among all environmental conditions

\section{4. 結}

(1) 相対湿度の影響 : 空気中で相刘湿度を $70 \%$ の高湿 度に制御した場合，蒸留水中と比較してむしろ低い 疲労強度を示した.これは溶液中とは違い，酸素の 供給が潤沢であったためであると考えられる。一方 $50 \%$ 以下の低湿度では強度は著しく向上し疲労限が 存在した.なお湿度の影響は高サイクル領域でのみ 見られた。

（2）溶液の影響 : 夕イヤ内水分溶液を $\mathrm{NaCl}$ に変えて も，またその濃度を $0.1 \%$ に薄めても疲労強度に影 響はない. $\mathrm{Cl}^{-}$の濃縮による孔食型の局所腐食が支 配的である. 溶液を蒸留水に代えることで, 疲労強 度はある程度上昇するが, 疲労限はみられない。 な お浸漬時間が相対的に短い低サイクル領域では $\mathrm{NaCl}$ の濃度が薄いと, き裂先端への $\mathrm{Cl}^{-}$の供給が 不十分で, 強度は蒸留水のそれに接近する.

（3） PH の影響 : PH12 の強アルカリ領域で，線材の表 面に安定な不動態が形成されるために, 疲労限が見 られる. PH7,10 では局所腐食, $\mathrm{PH} 2$ では全面腐食 となる.

(4) 溶存酸素の影響 : 酸素を脱気すると高サイクルの みならず低サイクル領域の疲労強度も上昇する. 脱 気による上昇の程度はあまり大きくなく, 疲労限は 見られないが, 孔食型の腐食は見られなくなる.

\section{解}

岩手大学大学院工学研究科機械工学専攻、高橋邦徳 君には実験等でお世話になった。また岩手大学工学部 工作センター、佐々木圭一技術専門職員には実験治具 並びに試験片の製作でお世話になった。ここに御礼を 申し上げる。

\section{考文献}

(1) 佐藤正ら, 機論, 60574, A(1994), 1333

(2) 遠藤吉郎ら, 機論, 23-131,A(1957), 484

(3) 江原隆一郎, 機論, 59557, A(1993), 1

(4) 佐藤正ら, 機論, 64626, A(1998), 2508

(5) K. Katagin, et al., Fatigue Fract. Eng. Mater. Struct. 22(1999), 753

（6）岩元兼敏, 機論, $30212, A(1964), 500$

（7）伊藤五郎，腐食科学と防食技術，(1969)，298，コ口 ナ社

（8）小賀正樹ら，材料，27，292(1977)

(9) 上田太郎, 上田祐男, 材料試験, 9, 78(1960)

(10) 後藤真宏ら, 機論, $57-542, \mathrm{~A}(1991), 36$

(11) Y-Z Wang, et al, Fatigue Fract. Eng. Mater. Struct. 18(1995), 293

(12) C. J. Cronetal ,Comosion, 27(1971), 1 